\title{
Unexpected malignancy diagnosed in presumed symptomatic and asymptomatic endometrial polyps and submucosal myomas after hysteroscopic resection
}

\author{
Utajony nowotwór złośliwy rozpoznany w objawowych i bezobjawowych zmianach \\ podejrzanych o polipa endometrialnego i mięśniaka podśluzówkowego \\ po resekcji histeroskopowej
}

\author{
Department of Gynecology and Oncology, Jagiellonian University, Krakow, Poland \\ Correspondence: Associate Professor Artur Ludwin, MD, PhD, Department of Gynecology and Oncology, Jagiellonian University, Kopernika 23, 31-501 Krakow, Poland, \\ tel.: +48 1242485 60, fax: +48 1242485 84, e-mail: ludwin@cm-uj.krakow.pl \\ Dr hab. n. med. Artur Ludwin, Oddział Klinizzny Ginekologii i Onkologii, Uniwersytet Jagielloński - Collegium Medicum, ul. Kopernika 23, 31-501 Kraków, tel.: +48 1242485 60, faks: +48 12 42485 84, \\ e-mail: ludwin@cm-uj.krakow.pl
}

\begin{abstract}
Hysteroscopy is the treatment of choice of benign intrauterine conditions, whenever feasible. During hysteroscopic procedures performed with the intent of resecting myomas and polyps, there is a potential risk of an unexpected diagnosis of an occult malignant lesion. Objective: To estimate the incidence of occult uterine malignancy in women undergoing hysteroscopic electroresection due to a diagnosis of benign uterine lesions: endometrial polyps and submucosal myomas, by ultrasound. Material and methods: The electronic database of patients hospitalized between January 2010 and December 2016 in the Department of Gynecology and Oncology of the Jagiellonian University was searched for women who had undergone hysteroscopic surgery due to presumed endometrial polyps and submucosal myomas. Medical records of 1,006 eligible women were analyzed. Results: Ten cases $(10 / 1,006 ; 1 \%)$ of occult endometrial cancer, 2 cases $(2 / 1,006 ; 0,2 \%)$ of low-grade endometrial stromal sarcoma and 3 cases $(3 / 1,006 ; 0,3 \%)$ of atypical endometrial hyperplasia were found postoperatively. One case of ovarian cancer coexisting with endometrial cancer was diagnosed. Of the factors analyzed, only age, menopausal status and abnormal uterine bleeding turned out to be significant endometrial cancer risk factors. Too few sarcoma cases did not allow similar estimates. We did not observe worsening of the prognosis, and all 15 patients who underwent hysteroscopic resection of the unforeseen malignancy or precancerous lesion are still alive within 2-8 years of follow-up. Conclusions: The incidence of unlooked-for malignancy in patients with benign intracavitary lesions, i.e. endometrial polyps and submucosal myomas, is relatively high. No negative effects of hysteroscopic resection on potential further treatment and prognosis have been proven so far. High risk of malignancy in women with presumed benign intracavitary lesions may indicate that not all these women are appropriate candidates for laparoscopic procedures with power morcellation, particularly when no previous histopathological verification is ordered.
\end{abstract}

Keywords: hysteroscopy, occult malignancy, endometrial cancer

Streszczenie Histeroskopia jest leczeniem z wyboru łagodnych zmian wewnątrzmacicznych. Podczas zabiegów histeroskopowych wykonywanych z zamiarem wycięcia mięśniaków podśluzówkowych i polipów endometrialnych istnieje potencjalne ryzyko nieoczekiwanego rozpoznania utajonego nowotworu złośliwego. Cel: Ocena częstości występowania utajonego nowotworu złośliwego trzonu macicy u kobiet poddawanych histeroskopowej elektroresekcji z powodu ultrasonograficznej diagnozy łagodnych zmian: polipa endometrialnego i/lub mięśniaka podśluzówkowego. Materiał i metody: Wykorzystując elektroniczną bazę danych archiwalnych Kliniki Ginekologii i Onkologii Uniwersytetu Jagiellońskiego, wyszukano pacjentki poddane histeroskopii operacyjnej w przedziale czasowym od stycznia 2010 do grudnia 2016 roku. Przeanalizowano dokumentację medyczną 1006 kwalifikujących się kobiet. Wyniki: W preparatach tkankowych z histeroskopii stwierdzono 10 przypadków (10/1006; 1\%) ukrytego raka endometrium, 2 przypadki (2/1006; 0,2\%) mięsaka i 3 przypadki $(3 / 1006 ; 0,3 \%)$ atypowego rozrostu endometrium. Odnotowano jeden przypadek raka jajnika współistniejącego z rakiem endometrium. 
Spośród analizowanych zmiennych jedynie wiek, status menopauzalny i nieprawidłowe krwawienie maciczne okazały się znaczącymi czynnikami ryzyka raka endometrium. Znikoma liczba przypadków utajonego mięsaka nie pozwoliła na podobne oszacowania. Nie zaobserwowano pogorszenia rokowania, a wszystkie 15 kobiet poddanych histeroskopowej resekcji niewykrytego nowotworu złośliwego lub stanu przednowotworowego pozostaje przy życiu w ciągu 2-8 lat obserwacji. Wnioski: Częstość występowania utajonych nowotworów złośliwych u pacjentek z łagodnymi zmianami wewnątrzjamowymi, tj. polipami endometrialnymi i mięśniakami podśluzówkowymi, jest stosunkowo wysoka. Dotychczas nie udowodniono negatywnego wpływu resekcji histeroskopowej na ewentualne dalsze leczenie i rokowanie. Wysokie ryzyko nowotworów złośliwych u kobiet z prawdopodobnie łagodnymi zmianami wewnątrzjamowymi może wskazywać na to, że nie wszystkie te kobiety są odpowiednimi kandydatkami do zabiegów laparoskopowych z użyciem morcelacji elektromechanicznej, zwłaszcza gdy rezygnuje się z przedoperacyjnej weryfikacji histopatologicznej endometrium.

Słowa kluczowe: histeroskopia, utajony nowotwór złośliwy, rak endometrium

\section{INTRODUCTION}

$\mathrm{H}$ ysteroscopy is the treatment of choice of symptomatic benign intrauterine lesions, such as submucosal myomas and uterine polyps. During hysteroscopic procedures performed with the intent of resection of myomas or polyps, there is a potential risk of an accidental diagnosis of an occult malign tumor, i.a. sarcoma and endometrial cancer (EC). The risk of malignancy in endometrial polyps reported by the American Association of Gynecologic Laparoscopists (AAGL) is estimated to vary between $0 \%$ and $12.9 \%{ }^{(1)}$. Most often, uterine cavity pathologies are recognized based on the accompanying symptoms, i.e. abnormal uterine bleeding (AUB): AUB-Polyp (AUB-P) in association with endometrial polyp and AUB-Leiomyoma (AUB-L) in association with submucosal myoma, according to the International Federation of Gynecology and Obstetrics (FIGO) nomenclature: the PALM-COEIN classification in women of reproductive age $\mathrm{e}^{(2)}$, or in women with postmenopausal bleeding $(\mathrm{PMB})^{(1)}$. It should be noted that, in asymptomatic women who undergo a gynecological examination with transvaginal ultrasound, endometrial polyps and submucosal myomas are commonly diagnosed. Patients with these benign lesions, not only symptomatic, but also asymptomatic, are commonly treated by means of hysteroscopy. However, surgery of asymptomatic benign lesions is a subject of debate without support by robust evidence. One of the arguments is the possibility of a histological examination of removed tissue allowing the exclusion of premalignant conditions and malignancy. The literature shows that some factors, such as AUB, postmenopausal status, $\mathrm{PMB}$, age $>60$ years, diabetes mellitus, arterial hypertension, obesity, and hormonal therapy, may be associated with higher risk of premalignant and malignant lesions ${ }^{(3)}$.

Although, hysteroscopy is considered a gold standard procedure for removal of benign intrauterine lesions, there is a potential risk of spreading neoplastic cells when resecting an unexpected malignant tumor. During hysteroscopic procedures, the uterine cavity is dilated with the medium under pressure ${ }^{(4)}$. In this case, uterine occult malignant tissue is a potential risk of tumor cell passage into the abdom-
However, despite these potential threats, hysteroscopy is considered the most accurate method of diagnosing $\mathrm{EC}^{(5,6)}$. It is believed that the risk of neoplastic cell passage when using lower medium pressure $(25-45 \mathrm{~mm} \mathrm{Hg})$ is small ${ }^{(7)}$. Nevertheless, during operative hysteroscopy performed for benign lesions, higher pressures (70-110 $\mathrm{mm} \mathrm{Hg}$ ) are usually needed, which increases the risk of tumor cell release to the peritoneal cavity. Research on the impact of tumor cell spread into the peritoneal cavity on patient survival in women subjected to accidental hysteroscopic resection of an unexpected uterine malignancy involves a few series of cases $^{(8)}$. Studies estimating the incidence of unforeseen malignancy during operative hysteroscopy with the intention of treating benign lesions are scarce ${ }^{(9)}$. However, both symptomatic and asymptomatic patients as well as clinicians wish to know the risk of malignant neoplasm when ultrasonographic suspicion of benign tumor is made. The primary aim of this study was to estimate the incidence of occult uterine malignancy in women undergoing hysteroscopic electroresection due to ultrasonographic diagnosis of benign uterine lesions: endometrial polyps and submucosal myomas. The secondary aims were (i) to estimate and compare the incidence of unexpected malignancy in symptomatic and asymptomatic women as well as those with and without AUB and PMB, and (ii) to assess potential factors for malignant lesions. Finally, we showed available data from the follow-up of patients with accidentally resected malignant tumors.

\section{MATERIAL AND METHODS}

\section{Study design}

This retrospective cohort study was based on archival data of the Department of Gynecology and Oncology of the Jagiellonian University in Krakow, Poland. The consent was obtained from the local bioethics committee to carry out the study. Medical data were extracted from electronic databases as well as traditional documentation, using codes from the International Statistical Classification of Diseases and Related Health Problems (ICD-10) and the International Classification of Medical Procedures (ICD-9), targeted for endometrial polyp (N84.0), submucosal myoma 
(D25.0) and hysteroscopic resection of the lesion in the uterus (68.234). Patients' demographic and clinical data, i.e. preoperative diagnosis, reported symptoms, indications to surgical treatment, postoperative diagnosis and histopathological findings, were obtained.

The inclusion criterion was the selection for hysteroscopic electroresection of a uterine lesion. Women undergoing hysteroscopic endometrial ablation, electroresection or biopsy, hysteroscopic metroplasty, hysteroscopic resection of retained placental tissue, hysteroscopic resection of cesarean scar defect, hysteroscopic synechiotomy, and hysteroscopic IUD (intrauterine device) removal were not considered eligible for the study. Women suffering from previously diagnosed EC or atypical endometrial hyperplasia $(\mathrm{AH})$ were also considered ineligible, while women with a diagnosis of indeterminate intracavitary lesions suspected of endometrial polyps and submucosal myomas were included in the study.

In order to estimate the risk of an accidental diagnosis of occult uterine malignancies during operative hysteroscopy performed due to a submucosal leiomyoma and uterine polyp, all hysteroscopic procedures performed in 2010-2016 were counted, taking into account the abovementioned criteria.

\section{Presurgical assessment}

All women were examined and then considered candidates for surgical treatment by a physician who was a specialist in obstetrics and gynecology or gynecological oncology. The gynecological examination was performed in a standardized way and consisted of a speculum and bimanual examination, transvaginal ultrasonography, and was followed by detailed counseling. All patients had cervical cytology done within the last 12 months.

Symptomatic patients reporting heavy menstrual bleeding, intermenstrual bleeding, postmenopausal bleeding, recurrent miscarriages or infertility were deemed eligible for hysteroscopy. In some cases, after taking into account the results of gynecological and ultrasound exams and considering risk factors, asymptomatic patients were also selected. All patients agreed to the proposed surgical treatment.

\section{Surgery}

Hysteroscopic procedures were performed within the operating theatre of the Department of Gynecology and Oncology under general anesthesia. Surgeons representing various levels of expertise in hysteroscopy performed the interventions: from physicians during residency training in cases of polyps to experienced gynecologists in cases of submucosal myomas of grade $0(\mathrm{G} 0)$ and 1 (G1) by the European Society for Hysteroscopy (ESH)/PALM-COEIN classifications ${ }^{(2)}$. The most difficult procedures of excising grade 2 (G2) submucosal myomas with deep penetration of the myometrium, as well as large G0 and G1 submucosal myomas $(>3 \mathrm{~cm})$, were performed by highly experienced hysteroscopists. Transrectal ultrasound was used in selected cases of fibroids with deep penetration of the myometrium (G2 according to PALM-COEIN/ESH) ${ }^{(10)}$. The operating theatre was equipped with KARL STORZ endoscopic instruments throughout the observation period. During surgical procedures, different tools were used, mainly monopoloar and bipolar resectoscopes (26 Fr) and $4 \mathrm{~mm}$ oblique view $\left(30^{\circ}\right)$ optics. Polyps and myomas were removed with the use of loop electrodes. In cases where no suspicious lesions in the uterine cavity were found in hysteroscopy, an endometrial biopsy was performed. During surgery, efforts were made not to exceed the pressure of $120 \mathrm{~mm} \mathrm{Hg}$ in the uterine cavity. Saline or Purisole (Fresenius, Bad Homburg, Germany) were used as the dilating medium. The collected tissue material was fixed in $10 \%$ formalin and sent for pathological verification.

\section{Histological examination}

Tissue specimens were evaluated in the Department of Pathomorphology of the Jagiellonian University in Krakow. In debatable cases, specimens were referred to an expert pathologist to assure the highest quality of histological evaluation.

\section{Statistical analysis}

The qualitative variables were described using frequencies $(n)$ and percentages (\%). The quantitative variables were described with means and standard deviations (SDs) when they were normally distributed, and using quartiles otherwise. Congruence with normal distribution was tested using Kolmogorov-Smirnov test. Correlations between analyzed variables were estimated using Cramer's V coefficient for qualitative variables. Differences between means of normally distributed variables between two groups were assessed using Student's $t$-test for independent samples, whereas differences in distributions of non-normally distributed ones were tested using Mann-Whitney test.

\section{RESULTS}

\section{Patients' characteristics}

Using the above-mentioned search criteria as well as inclusion and exclusion criteria, records of 1,006 women were obtained and then analyzed. Six hundred and fifty-four women $(654 / 1,006 ; 65 \%)$ were younger than 45 years of age $(65 \%)$, and 352 were 45 years old and older (35\%). Eight hundred and eighteen women $(818 / 1,006 ; 81,3 \%)$ were at premenopausal age and $188(18,7 \%)$ were postmenopausal. Women who gave birth at least once accounted for $62.2 \%$ of the study population and nulliparous women constituted $37.8 \%$. Characteristics of the study population, like median age, body mass index (BMI), gravidity, parity, hemoglobin level and surgery time, are shown in Tab. 1. 


\begin{tabular}{|l|c|c|c|c|c|c|c|c|c|}
\hline & Mean & $\mathbf{- 9 5 \%} \mathrm{Cl}$ & $+\mathbf{9 5 \%} \mathrm{Cl}$ & $\mathbf{S D}$ & Min & Max & Median & $\begin{array}{c}\text { Lower } \\
\text { quartile }\end{array}$ & $\begin{array}{c}\text { Upper } \\
\text { quartile }\end{array}$ \\
\hline Age & 43 & 43 & 44 & 12 & 17 & 84 & 42 & 35 & 49 \\
\hline BMI & 24.71 & 24.40 & 25.01 & 4.91 & 13.21 & 53.51 & 24.00 & 21.26 & 26.85 \\
\hline Gravidity & 1 & 1.25 & 1.41 & 1.27 & 0.00 & 7.00 & 1.00 & 0.00 & 2.00 \\
\hline Parity & 1 & 1.11 & 1.25 & 1.14 & 0.00 & 6.00 & 1.00 & 0.00 & 2.00 \\
\hline Hemoglobin (g/dL) & 12.79 & 12.67 & 12.90 & 1.47 & 5.30 & 22.30 & 13.00 & 12.10 & 13.80 \\
\hline Surgery time (min.) & 50.28 & 49.06 & 51.50 & 19.42 & 10.00 & 205.00 & 45.00 & 40.00 & 60.00 \\
\hline
\end{tabular}

Tab. 1. Population characteristics

None of the quantitative variables had a normal distribution (in the Kolmogorov-Smirnov test $p<0.01$ ). Median age was 42 years (range 35-49 years) and median BMI was 24 (range 21.26-26.85). Median gravidity was 1 (range $0-2$ ) and median parity was also 1 (range $0-2$ ). Women, who were pregnant 4 times and more accounted for $5.3 \%$ of the population. Median preoperative hemoglobin level was $13 \mathrm{~g} / \mathrm{dL}$ (range 12.1-13.8). Median duration of surgery, from the beginning to the end of general anesthesia, was 45 minutes (range 40-60).

The primary indication for surgery was an endometrial polyp (84.6\%) and a submucosal myoma (11.9\%), rarely a fibroid coexisting with a polyp $(0.7 \%)$. Pathology of the uterine cavity with an indeterminate ultrasound character was detected in $2.8 \%$ of women (Tab. 2 ).

The most frequently reported symptom was AUB, i.e. heavy menstrual bleeding (HMB; 36.2\%), irregular menstrual bleeding (IMB; 11.2\%), heavy and irregular menstrual bleeding (HMB/IMB; 8.5\%) and PMB (4.5\%). 39.6\% of women did not report any abnormal uterine bleeding. In $7.1 \%$ of women, the indication for surgery was infertility. Pelvic pain was reported by $13.8 \%$ of women. In some women, the coexistence of two or more symptoms was observed, hence the sum in Tab. 3 exceeds $100 \%$.

\section{Adverse events and complications of surgery}

Four complications were noted: perforation of the uterine wall in 2 cases with subsequent laparoscopic suturing, single overload syndrome and one case of postoperative infection (adnexitis).

\begin{tabular}{|l|c|c|}
\hline Preoperative diagnosis of uterine cavity & N & $\%$ \\
\hline Myoma & 120 & 11.9 \\
\hline Polyp & 851 & 84.6 \\
\hline Polyp + myoma & 7 & 0.7 \\
\hline Inconclusive diagnosis & 28 & 2.8 \\
\hline $\begin{array}{l}\text { N=1,006 women. } \\
\text { Inconclusive diagnosis - polyp or polypous endometrium or myoma. }\end{array}$ \\
\hline
\end{tabular}

Tab. 2. Preoperative diagnosis of the uterine cavity

\section{Benign intracavitary lesions: endometrial polyps and submucosal myomas}

The study involved 1,006 women with presumed endometrial polyps, submucosal myomas, submucosal myomas coexisting with polyps, and those with inconclusive benign conditions suspected of a myoma or a polyp. In this population of women, 12 patients $(12 / 1,006 ; 1.2 \%)$ were postoperatively diagnosed with a malignancy: 10 with EC and 2 with endometrial stromal sarcoma (ESS). Detailed pathological findings are presented in Tab. 4.

\section{Presumed endometrial polyps and malignancy}

There were $851 / 1,006(84.6 \%)$ patients with an initial diagnosis of an endometrial polyp, 7/1,006 (0.7\%) with both an endometrial polyp and a submucosal myoma, and 28/1,006 $(2.8 \%)$ with an inconclusive ultrasonographic diagnosis as to a uterine polyp or submucosal myoma. Considering all these diagnoses as potential endometrial polyps, there were

\begin{tabular}{|c|c|c|}
\hline Reported symptoms & $N$ & $\%$ \\
\hline Symptomatic: & 696 & 69.2 \\
\hline - AUB/PMB & 608 & 60.4 \\
\hline - Infertility & 71 & 7.1 \\
\hline - Pain & 139 & 13.8 \\
\hline Asymptomatic & 310 & 30.8 \\
\hline$A U B+P M B$ & 608 & 60.4 \\
\hline No AUB + PMB & 398 & 39.6 \\
\hline AUB: & 563 & 56.0 \\
\hline - AUB/HMB & 364 & 36.2 \\
\hline - AUB/IMB & 113 & 11.2 \\
\hline - AUB-HMB/IMB & 86 & 8.5 \\
\hline PMB & 45 & 4.5 \\
\hline \multicolumn{3}{|c|}{$\begin{array}{l}N=1,006 \text { women. } \\
\text { AUB/PMB - abnormal uterine bleeding and postmenopausal bleed- } \\
\text { ing; AUB - abnormal uterine bleeding; PMB - postmenopausal bleeding; } \\
\text { AUB/HMB - heavy menstrual bleeding; AUB/IMB - irregular menstrual } \\
\text { bleeding; AUB-HMB/IMB - heavy and irregular menstrual bleeding. }\end{array}$} \\
\hline
\end{tabular}

Tab. 3. Reported symptoms 
$886 / 1,006(88.1 \%)$ women with presumed polyps. Within this group, malignant lesions were recognized in $11 / 886$ (1.2\%) women: EC in 10/886 (1\%) and ESS in 1/866 (0.1\%). Among women with a conclusive ultrasonographic diagnosis of an endometrial polyp alone, ten out of $851(10 / 851$; $1.2 \%)$ were diagnosed with malignancies, i.e. EC in $9 / 851$ (1.1\%) and ESS in $1 / 851(0.1 \%)$. In the group of women with $\mathrm{AUB} / \mathrm{PMB}$ and a conclusive diagnosis of an endometrial polyp alone, there were 6/492 (1.2\%) malignancies (5 EC and 1 ESS). Among patients suffering from AUB/PMB with a preoperative diagnosis of a polyp, a polyp coexisting with a submucosal myoma and an inconclusive diagnosis, 6 cases of malignancy $(6 / 513 ; 1.7 \%)$ were postoperatively diagnosed.

\section{Presumed submucosal myomas and malignancy}

There were $120(120 / 1,006 ; 11.9 \%)$ patients with an initial diagnosis of a submucosal myoma, 7/1,006 (0.7\%) with both an endometrial polyp and a submucosal myoma, and $28 / 1,006(2.8 \%)$ with a diagnosis uncertain as to a polyp or submucosal myoma. Considering all the above diagnoses as potential submucosal myomas, there were 155 (155/1006; $15.4 \%)$ women with presumed submucosal myomas. In this group, $2(2 / 155 ; 1.3 \%)$ malignancies (1 ESS and 1 EC) were postoperatively recognized. Taking into account only women with submucosal myomas, there was one case of ESS (1/120; $1.7 \%)$. Among patients suffering from $\mathrm{AUB} / \mathrm{PMB}$ with a preoperative diagnosis of a submucosal myoma, both a polyp and a submucosal myoma, and an inconclusive diagnosis, 2 (2/116; $1.7 \%)$ cases of malignancy (1 EC and $1 \mathrm{ESS})$ were postoperatively diagnosed.

\section{Malignancy, symptoms and abnormal uterine bleeding/postmenopausal bleeding}

Malignancy was present in 9/696 (1.3\%) and 3/310 (1.0\%) symptomatic (AUB/PMB, pelvic pain or infertility) and

\begin{tabular}{|l|c|c|}
\hline Histology & N & $\%$ \\
\hline Endometrial stromal sarcoma & 2 & 0.2 \\
\hline Endometrial cancer & 10 & 1.0 \\
\hline Atypical hyperplasia & 3 & 0.3 \\
\hline Polypoid endometrium & 269 & 26.7 \\
\hline Endometrial polyp & 409 & 40.7 \\
\hline Submucous myoma & 131 & 13.0 \\
\hline Polyp + submucous myoma & 12 & 1.2 \\
\hline Normal endometrium + other benign conditions* & 167 & 16.6 \\
\hline No histological result & 3 & 0.3 \\
\hline $\begin{array}{l}N=1,006 \text { women. } \\
\text { * Endometrial hyperplasia without atypia, adenomyoma, adenomyomatous } \\
\text { polyp, adenomyosis, cellular leiomyoma, disordered proliferative endome- } \\
\text { trium, fibroadenoma. }\end{array}$ \\
\hline
\end{tabular}

Tab. 4. Pathological findings asymptomatic women, respectively. Relative risk of unexpected malignancy in symptomatic women in comparison to asymptomatic ones was 1.3 (95\% confidence interval, CI: 0.4 to $4.9, p=0.7)$. Malignancy was present in $8 / 608(1.3 \%)$ and $4 / 398(1.0 \%)$ women with $\mathrm{AUB} / \mathrm{PMB}$ and without AUB/PMB, respectively. There were 6 cases of EC and 2 cases of ESS among women with AUB/PMB and 4 cases of EC in women without $\mathrm{AUB} / \mathrm{PMB}$. Relative risk of occult malignancy in women with $\mathrm{AUB} / \mathrm{PMB}$ in comparison to those without $\mathrm{AUB} / \mathrm{PMB}$ was 1.3 (95\% CI: 0.4 to $4.3, p=0.7$ ).

\section{Endometrial cancer}

There was a significant difference in the mean age of women with EC compared to the population average (54.8 vs. 43.3 ; $p=0.005)$. There was a significant correlation between EC and the type of uterine bleeding ( $p=0.005$; Cramer's $\mathrm{V}=0.14)$. Most often, cancer was diagnosed in women with PMB (6.7\%), followed by women with HMB/IMB (1.2\%), HMB (0.6\%) and no AUB (0.5\%). There was no EC in the group of women with IMB. EC was diagnosed significantly more frequently in the group of postmenopausal women compared to premenopausal ones $(2.3 \%$ vs. $0.5 \%$; $p=0.04$, Cramer's V $=0.08$ ).

There was no significant relationship between histologically confirmed EC and the number of pregnancies and deliveries, surgery time, hemoglobin level, infertility, abdominal pain, hypertension, diabetes, smoking, BMI or breast cancer.

\section{Survival rate of patients with unexpected malignancy}

We did not observe worsening of prognosis in any patient with unexpected EC or ESS. All patients were still alive after 2-5 years of follow-up.

\section{DISCUSSION}

The study found that unexpected malignancy occurred in 1:84 and, including the precancerous condition $(\mathrm{AH})$, in 1:67 hysteroscopies performed in women with presumed benign lesions, i.e. endometrial polyps and submucosal myomas. An unexpected malignant tumor was present in 1:77 and 1:103 symptomatic (AUB, PMB, pelvic pain, infertility) and asymptomatic women, respectively. Similarly, considering the presence of $\mathrm{AUB} / \mathrm{PMB}$, occult malignancy was diagnosed in 1:76 and 1:100 women with and without AUB/PMB, respectively. In the examined population of 1,006 women with a preoperative suspicion of a polyp or a myoma, the total of 15 patients $(1.5 \%)$ were diagnosed with a malignancy or precancerous condition. Malignancy was present in 11/886 (1.2\%) and in 2/155 (1.3\%) women with an ultrasonographic diagnosis of a polyp and submucosal myoma, respectively. In the course of the study, it was confirmed that all patients were still alive until December 2018. Hence, the application of operative hysteroscopy with 
the intention of treating benign lesions allowed to recognize malignant tumors without worsening the prognosis during a short-term observation (2-5 years).

It should be highlighted that our results on the incidence of occult malignancy are calculated in relation to an initial ultrasound diagnosis of intracavitary lesions: polyps, myomas or an inconclusive diagnosis of a polyp or myoma. This manner of calculating the risk seemed the most appropriate, taking into account routine clinical practice, in which one must answer the question about the risk of malignant tumor in the presence of given ultrasound features.

The question about the potential risk formulated in this way seems to be more appropriate for clinicians than the question about the chance of malignant tumor when performing diagnostic hysteroscopy or panoramic view hysteroscopy due to the fact that nowadays the management is based on initial diagnosis and symptoms.

Moreover, the necessity of invasive diagnosis and treatment of submucosal myomas and polyps is a subject of debate. According to our study results, there were no significant differences in the incidence of an unexpected malignancy in symptomatic and asymptomatic women with presumed benign intracavitary lesions. It seems that more accurate diagnosis, like sonohysterography, may be an alternative to hysteroscopy in such cases. Our results implicate also that overall diagnostic accuracy of unenhanced ultrasound performed by different examiners with various levels of expertise is limited. Only in a part of women with a preoperative diagnosis of a polyp or myoma was the initial suspicion histologically confirmed, especially with regard to a polyp.

The weak points of our study are: (i) a retrospective design, (ii) a single center database, and (iii) lower than expected accuracy of primary diagnosis. However, the results reflect everyday clinical practice, and therefore probably better represent the real diagnostic accuracy of ultrasonography in various hands, with a probably higher number of those with basic expertise.

The strengths of the study are: (i) the database of prospectively included all consecutive patients with an initial diagnosis of an endometrial polyp and submucosal myoma who underwent operative hysteroscopy with the intention of benign lesion treatment, (ii) inclusion of a relatively large group of asymptomatic patients who commonly remain under medical observation without surgical intervention in other centers, and (iii) the lack of a specific definition of a polyp ${ }^{(11)}$, resulting in the heterogeneity of initial diagnoses depending on the observer experience, and also regarding diagnoses made by physicians responsible for the selection for the targeted treatment.

As already mentioned, the real impact of neoplastic cell leakage into the peritoneal cavity on overall survival is not known due to the lack of randomized prospective studies $^{(12-14)}$. Of the ten EC women in our study, only one is known to have had a positive peritoneal cytology, and it was a patient with concurrent ovarian cancer. Even cytology
When it comes to myomas, the incidence varies from $70 \%$ to $80 \%$, depending on the human race ${ }^{(15)}$. Hysteroscopy is the preferred method of treatment for fibroids, whenever feasible ${ }^{(16)}$. Data on the incidence of malignant tumors during hysteroscopic resection of submucosal myomas are not as numerous as in the case of endometrial polyps; also the risk factors are less explored. The above issues as well as doubts regarding prognosis are discussed in the literature mainly in case reports, which indirectly indicates their rare occurrence. In the population studied, 2 patients were diagnosed with ESS, and the reason for the surgery was HMB. A polyp was suspected as the underlying cause of HMB in one patient and a myoma in the other. Hence, it is possible to calculate the ESS risk in the population of women with $\mathrm{HMB}$, which in our study amounted was $0.55 \%$ (2/364). Considering all women with AUB, this risk was $0.33 \%(2 / 608)$. The literature data show that the risk of ESS is $1 / 800$ in women undergoing endometrial ablation due to $\mathrm{AUB}^{(17)}$.

As already mentioned, hysteroscopic excision of localized lesions, apart from specific cases, is not sufficient for the treatment of malignant tumors. However, in one of our two patients with ESS diagnosed in the specimen from hysteroscopic resection, no malignancy was found in the material from the main surgery, which means that the tumor had been removed completely during the previous procedure. What is even more interesting, the discussed patient underwent hysteroscopy twice: after the first surgery, smooth muscle tumor of uncertain malignant potential (STUMP) was diagnosed, which was the reason for the next procedure, after which ESS was diagnosed. On the other hand, there are attempts to treat this type of cancer preserving fertility ${ }^{(18,19)}$ with different results. However, both patients were subjected to further hysterectomy with bilateral salpingectomy via laparotomy, and there was no trace of dissemination in the peritoneal cavity in any of them. Similarly, the results of other studies do not indicate a worse prognosis in the case of tumors other than EC when recognized in a tissue specimen from hysteroscopy ${ }^{(20)}$.

The main implication of the current study is that the incidence of unexpected malignancy in patients subjected to hysteroscopy with the intention to treat benign intracavitary lesions, i.e. endometrial polyps and myomas is relatively high. For instance, the risk of occult malignancy in women subjected to laparoscopic supracervical hysterectomy is lower than the risk of occult malignancy in all presumed myomas: intramural, subserosal, submucosal and hybrid according to the PALM-COEIN ${ }^{(21-23)}$. In our cohort, there was no significant difference in the incidence of malignancy between symptomatic and asymptomatic women. Taking into consideration all women with benign intracavitary lesions as a target group and ignoring the type of lesion and the presence or absence of symptoms, it might be reasonable to implement hysteroscopic surgery in all women with a suspicion of the above-mentioned benign conditions due to relatively high prevalence of malignancy. 
A high survival rate after operative hysteroscopy in cases of an unexpected uterine malignancy may indicate that its benefits in the treatment of presumed benign lesions are greater than potential concerns, i.e. spreading neoplastic cells or worse prognosis ${ }^{(7,24-26)}$. An indirect implication of this study is that the implementation of procedures with high-power morcellation, such as laparoscopic supracervical hysterectomy, in cases of presumed benign intrauterine lesions, like endometrial polyps and myomas, should be avoided due to a very high risk of occult malignancy (greater than 1:100). Further large prospective studies and randomized controlled trials should be performed in this field to guide the management of polyps and submucosal myomas in diverse groups of patients, considering the risks and benefits for specific groups of patients (i.e. asymptomatic women), and safety of expectant and surgical management (hysteroscopic resection).

\section{CONCLUSIONS}

The incidence of unlooked-for malignancy in benign intracavitary lesions, i.e. endometrial polyps and submucosal myomas, in women diagnosed by clinicians of various expertise in ultrasound is relatively high and greater than $1: 100$, which may justify performing hysteroscopic procedures in symptomatic and asymptomatic women, especially after menopause. Laparoscopic procedures with power morcellation not preceded by previous endometrial sampling should not be considered as an alternative to hysteroscopic procedures, due to a high risk of occult malignancy in presumed benign intracavitary lesions.

\section{Funding/conflict of interest}

This study received no funding, and the authors have no conflicts of interest to declare.

\section{References}

1. American Association of Gynecologic Laparoscopists: AAGL practice report: practice guidelines for the diagnosis and management of endometrial polyps. J Minim Invasive Gynecol 2012; 19: 3-10.

2. Munro MG, Critchley HO, Broder MS et al.; FIGO Working Group on Menstrual Disorders: FIGO classification system (PALM-COEIN) for causes of abnormal uterine bleeding in nongravid women of reproductive age. Int J Gynaecol Obstet 2011; 113: 3-13.

3. Sasaki LMP, Andrade KRC, Figueiredo ACMG et al.: Factors associated with malignancy in hysteroscopically resected endometrial polyps: a systematic review and meta-analysis. J Minim Invasive Gynecol 2018; 25: 777-785.

4. Revel A, Tsafrir A, Anteby SO et al.: Does hysteroscopy produce intraperitoneal spread of endometrial cancer cells? Obstet Gynecol Surv 2004; 59: 280-284.

5. Ianieri MM, Staniscia T, Pontrelli G et al.: A new hysteroscopic risk scoring system for diagnosing endometrial hyperplasia and adenocarcinoma. J Minim Invasive Gynecol 2016; 23: 712-718.
6. Colombo N, Creutzberg C, Amant F et al.; ESMO-ESGO-ESTRO Endometrial Consensus Conference Working Group: ESMOESGO-ESTRO Consensus Conference on Endometrial Cancer: diagnosis, treatment and follow-up. Ann Oncol 2016; 27: 16-41.

7. Polyzos NP, Mauri D, Tsioras S et al.: Intraperitoneal dissemination of endometrial cancer cells after hysteroscopy: a systematic review and meta-analysis. Int J Gynecol Cancer 2010; 20: 261-267.

8. Aumiphin J, Crochet P, Knight $\mathrm{S}$ et al.: Outcome and follow-up of patients with endometrial carcinoma diagnosed on operative hysteroscopic resection specimens. Anticancer Res 2016; 36: 4341-4345.

9. Lenci MA, Nascimento VA, Grandini AB et al.: Premalignant and malignant lesions in endometrial polyps in patients undergoing hysteroscopic polypectomy. Einstein (Sao Paulo) 2014; 12: 16-21.

10. Ludwin A, Ludwin I, Pityński K et al.: Transrectal ultrasoundguided hysteroscopic myomectomy of submucosal myomas with a varying degree of myometrial penetration. J Minim Invasive Gynecol 2013; 20: 672-685.

11. Finco A, Centini G, Lazzeri L et al.: Surgical management of abnormal uterine bleeding in fertile age women. Womens Health (Lond) 2015; 11: 513-525.

12. Obermair A, Geramou M, Gucer F et al.: Does hysteroscopy facilitate tumor cell dissemination? Incidence of peritoneal cytology from patients with early stage endometrial carcinoma following dilatation and curettage (D \& C) versus hysteroscopy and D \& C. Cancer 2000; 88: 139-143.

13. Bradley WH, Boente MP, Brooker D et al.: Hysteroscopy and cytology in endometrial cancer. Obstet Gynecol 2004; 104: 1030-1033.

14. Chen J, Clark LH, Kong WM et al.: Does hysteroscopy worsen prognosis in women with type II endometrial carcinoma? PLoS One 2017; 12: e0174226.

15. Donnez J, Dolmans MM: Uterine fibroid management: from the present to the future. Hum Reprod Update 2016; 22: 665-686.

16. Van Heertum K, Barmat L: Uterine fibroids associated with infertility. Womens Health (Lond) 2014; 10: 645-653.

17. Vilos GA, Harding PG, Sugimoto AK et al.: Hysteroscopic endomyometrial resection of three uterine sarcomas. J Am Assoc Gynecol Laparosc 2001; 8: 545-551.

18. Laurelli G, Falcone F, Scaffa C et al.: Fertility-sparing management of low-grade endometrial stromal sarcoma: analysis of an institutional series and review of the literature. Eur J Obstet Gynecol Reprod Biol 2015; 195: 61-66.

19. Xie W, Cao D, Yang J et al.: Fertility-sparing surgery for patients with low-grade endometrial stromal sarcoma. Oncotarget 2017; 8: 10602-10608.

20. Vilos GA, Edris F, Abu-Rafea B et al.: Miscellaneous uterine malignant neoplasms detected during hysteroscopic surgery. J Minim Invasive Gynecol 2009; 16: 318-325.

21. Ludwin A, Gawron I, Pityński K: Occult uterine leiomyosarcoma in women undergoing abdominal and minimally invasive surgeries for myomas. Ginekol Pol 2018; 89: 546-552.

22. Gawron I, Skotniczny K, Ludwin A: Occult uterine malignancy during laparoscopic supracervical hysterectomy. Ginekol Pol 2018; 89: 467-474.

23. Food and drug Administration: FDA Updated Assessment of The Use of Laparoscopic Power Morcellators to Treat Uterine Fibroids. December 2017. Available from: https://www.fda.gov/ downloads/MedicalDevices/ProductsandMedicalProcedures/ SurgeryandLifeSupport/UCM584539.pdf.

24. Takac I, Zegura B: Office hysteroscopy and the risk of microscopic extrauterine spread in endometrial cancer. Gynecol Oncol 2007; 107: 94-98.

25. Lo KWK, Cheung TH, Yim SF et al.: Hysteroscopic dissemination of endometrial carcinoma using carbon dioxide and normal saline: a retrospective study. Gynecol Oncol 2002; 84: 394-398.

26. Chang YN, Zhang Y, Wang YJ et al.: Effect of hysteroscopy on the peritoneal dissemination of endometrial cancer cells: a metaanalysis. Fertil Steril 2011; 96: 957-961. 